\title{
HUBUNGAN SIMULTAN BANK-FIRM RELATIONSHIP DAN KINERJA PADA PERUSAHAAN SOCIALLY RESPONSIBLE INVESTMENT (SRI) DI INDONESIA
}

\author{
Alyta Shabrina Zusryn* \\ Universitas YARSI, Indonesia \\ Maulida Nurul Innayah \\ Universitas Muhammadiyah Purwokerto, Indonesia \\ Hanastasya Sahulata \\ Universitas Gadjah Mada, Indonesia
}

\begin{abstract}
A bank-firm relationship in the company occurs when the bank as a lender can obtain more extensive information from other parties. This study aims to examine the simultaneous relationship between bank-firm relationships and company performance. The sample in this study is non-financial socially responsible investment (SRI) firms listed on the SRI KEHATI index. The data analysis method uses two-stage least square (2SLS). The results of this study found that only multiple-bank relationships had a positive and significant effect on company performance. In addition, the company's performance also influences the company's decision to conduct multiple-bank relationships. These results indicate a simultaneous relationship between multiple-bank relationships and the performance of companies that implement socially responsible investment (SRI) in Indonesia. Multiple-bank relationships provide convenience to banks in monitoring companies. While other indicator such as company relations with foreign banks, domestic banks, the number of banks and the bank loan ratio (BLR) were not significant in the simultaneous relationship. The implication of this research is that a company can conduct multiple-bank relationships to diversify external funding sources, reduce credit constraints and reduce strategy failures.
\end{abstract}

JEL : G21, G32, G1.

Keywords : financial performance, bank-firm relationships, responsible investment, simultaneous relationship.

\begin{abstract}
ABSTRAK
Terbentuknya bank-firm relationship terjadi ketika bank sebagai pemberi pinjaman dapat memperoleh informasi yang lebih luas dari pihak lainnya. Penelitian ini bertujuan untuk menguji hubungan simultan bank-firm relationship terhadap kinerja perusahaan. Perusahaan yang menjadi sampel adalah perusahaan non-keuangan socially responsible investment (SRI) yang terdaftar pada indeks SRI KEHATI. Metode analisis data menggunakan two-stage least square (2SLS). Hasil penelitian ini menemukan bahwa hanya multiple-bank relationship berpengaruh positif dan signifikan terhadap kinerja perusahaan. Selain itu, kinerja perusahaan juga bepengaruh terhadap keputusan perusahaan untuk melakukan multiple-bank relationship. Hasil tersebut menunjukkan adanya hubungan simultan antara multiple-bank relationship dan kinerja perusahaan yang menerapkan socially responsible investment (SRI) di Indonesia. Multiple-bank relationship memberikan kemudahan kepada bank dalam melakukan pengawasan perusahaan. Sementara indikator lain seperti hubungan perusahaan dengan bank asing, bank domestik, banyaknya bank dan bank loan ratio (BLR) tidak ada yang signifikan dalam hubungan simultan tersebut. Implikasi pada penelitian ini adalah perusahaan dapat melakukan multiple-bank relationship untuk diversifikasi sumber pendanaan eksternal, mengurangi kendala kredit dan mengurangi kegagalan strategi.
\end{abstract}

Kata Kunci : kinerja keuangan, bank-firm relationships, responsible investment, hubungan simultan.

"Email : alyta.shabrina@yarsi.ac.id

Received : 20-06-2020, Accepted : 26-08-2020, Published : 28-08-2020

P-ISSN : 2087-9954, E-ISSN : 2550-0066. DOI : http://dx.doi.org/10.26418/jebik.v9i2.40984 


\section{PENDAHULUAN}

Adanya akses perusahaan pada sumber pembiayaan eksternal menjadi penentu utama pertumbuhan perusahaan dan berdampak signifikan pada kinerja kegiatan bisnis (Angori, Aristei \& Gallo, 2019; Lee, 2020). Sistem keuangan pasar negara berkembang yang berorientasi pada bank, menyebabkan keputusan perusahaan untuk mendapatkan pendanaan eksternal menjadi bergantung dengan kondisi bank-firm relationship (Go'mez-Gonza'lez \& Reyes, 2011; Pantjes \& Tümer-Alkan, 2017; Tsapin, 2017). Bank-firm relationship (BFR) memungkinkan dapat mengurangi asimetri informasi dan meningkatkan akses kredit bisnis (Angori et al., 2019). Oleh karena itu, penelitian tentang bank-firm relationship (BFR) menjadi hal yang menarik untuk diteliti, khususnya di negara berkembang.

Bank-firm relationship dapat memberikan keuntungan bagi perusahaan dan bank (Angori et al., 2019; Liu, Fujiwara, Jinushi \& Yamori, 2016). Pada sisi bank, adanya hubungan dengan perusahaan mempermudah dalam memantau dan mendapatkan informasi tentang perusahaan (Aristei \& Gallo, 2017; Ghosh, 2017). Pada sisi perusahaan, multiple-bank relationship memungkinkan perusahaan untuk mendapatkan keuntungan yaitu pasokan kredit yang lebih stabil dan mengurangi risiko likuidasi proyek investasi (Jadiyappa, Sireesha, Hickman \& Jyothi, 2020). Selain itu, jika perusahaan melakukan multiple-bank relationship maka perusahaan tersebut memperoleh pinjaman tambahan dengan lebih mudah selama kesulitan keuangan (Jha, Shankar \& Arvi, 2014). BFR yang terjadi dalam jangka panjang dapat juga menimbulkan penggunaan pinjaman yang efisien bagi perusahaan (Stephan, Tsapin \& Talavera, 2014).

Bank-firm relationship juga dapat meningkatkan kinerja perusahaan dengan beberapa cara. Rajan (1992) mengemukakan bahwa BFR dapat menghindari terjadinya kekuatan monopoli atas informasi tentang perusahaan peminjam. Selanjutnya, multiple-bank relationship dapat mendiversifikasi risiko likuiditas (Rajan, 1992). Detragiache, Paolo \& Guiso (2000) menyatakan bahwa hubungan tersebut dapat mengurangi risiko likuidasi dini yang terjadi ketika perusahaan gagal memenuhi kewajiban hutangnya. Bolton \& Scharfstein (1996) menjelaskan bahwa multiplebank relationship dapat mengurangi kemungkinan kegagalan strategi, karena perusahaan pinjaman harus bernegosiasi dengan banyak kreditor.

Hindrayani (2017) menemukan bahwa BFR dan pertumbuhan penjualan berpengaruh positif dan signifikan terhadap kinerja keuangan perusahaan di Indonesia. Hasil yang sama juga terjadi pada penelitian Firdausi \& Sulung (2019) pada perusahaan non-keuangan di Indonesia. Namun pada beberapa penelitian terdahulu juga menemukan bahwa banyaknya bank firm relationship berpengaruh negatif terhadap kinerja dan nilai pasar perusahaan (Castelli, Dwyer \& Hasan, 2011; Fok, Chang \& Lee, 2004). Pada penelitian lainnya, Agarwal \& Elston (2001) menemukan bahwa BFR tidak berpengaruh terhadap kinerja. Berdasarkan uraian sebelumnya dapat dijelaskan bahwa hubungan bank-firm relationship belum konklusif.

Perbedaan bank-firm relationship juga dapat terjadi pada bank asing dan bank domestik. Fok et al. (2004) menemukan hubungan bank asing dengan perusahaan berpengaruh positif dan signifikan terhadap kinerja. Hasil yang berkebalikan terjadi pada hubungan bank domestik terhadap kinerja yang negatif dan signifikan. Pennathur \& Vishwasrao (2014) menemukan bahwa dalam penyaluran kredit, bank asing cenderung fokus pada perusahaan yang besar, tua dan mempunyai kinerja unggul. Pada posisi yang berbeda, bank domestik cenderung melayani perusahaan yang kecil dan mempunyai kinerja yang biasa saja (Pennathur \& Vishwasrao, 2014). 
Hal tersebut menunjukkan kinerja perusahaan dan bank-firm relationship berkaitan khususnya pada bank asing dan domestik.

Pada sisi lain, kondisi keuangan perusahaan juga dapat berpengaruh terhadap keputusan perusahaan dalam melakukan bank-firm relationship (Karaivanov, Saurina \& Townsend, 2019; Tsapin, 2017). Fok et al. (2004) menemukan bahwa kinerja perusahaan berpengaruh negatif dan signifikan terhadap banyaknya foreign bank-relationship di Taiwan. Hasil penelitian tersebut menunjukkan bahwa semakin baik kinerja keuangan maka akan semakin kecil kemungkinan perusahaan berhubungan dengan banyak bank asing. Hasil yang sama terjadi pada penelitian Ogawa, Sterken \& Tokutsu (2007) menemukan bahwa perusahaan di Jepang yang mempunyai hutang banyak dan memiliki aset yang sedikit cenderung melakukan multiple-bank relationship. Hasil tersebut berlawanan dengan penelitian Refait-Alexandre \& Serve (2020) pada perusahaan di Perancis yaitu perusahaan besar, memiliki kinerja baik dan inovatif cenderung akan memiliki hubungan dengan banyak bank.

Berdasarkan agency cost theory, hutang bank dapat mengurangi konflik antara manajer dengan pemegang saham (Jadiyappa et al., 2020; Mustapha \& Ahmad, 2011). Adanya peran ganda menyebabkan bank tidak hanya menjadi pemberi pinjaman saja, tetapi juga dapat melakukan pengawasan pada perusahaan peminjam (Firdausi \& Sulung, 2019; Fok et al., 2004). Keterlibatan bank dalam memonitor perusahaan dapat berpengaruh terhadap kinerja keuangan perusahaan (Dawar, 2014; Fok et al., 2004; Jadiyappa et al., 2020). Pada sisi lain, kinerja dan profitabilitas perusahaan menjadi faktor yang berpengaruh terhadap bank-firm relationship (Ogawa et al., 2007; Refait-Alexandre \& Serve, 2020). Berdasarkan uraian sebelumnya, tujuan pada penelitian ini adalah untuk menguji apakah terdapat hubungan simultan bank-firm relationship (BFR) dan kinerja perusahaan.

Beberapa penelitian terdahulu hanya meneliti hubungan bank-firm relationships (BFR) terhadap kinerja perusahaan saja di Indonesia (Hindrayani, 2017; Firdausi \& Sulung, 2019). Studi ini penting untuk dilakukan karena menguji hubungan BFR terhadap kinerja, dan sebaliknya. Kontribusi penelitian ini terdapat pada beberapa aspek. Pertama, studi ini menguji hubungan dua arah bank-firm relationship (BFR) dan kinerja perusahaan, yang penelitiannya masih terbatas di Indonesia. Kedua, fokus pada penelitian ini adalah perusahaan socially responsible investment (SRI) yang menerapkan konsep sosial, lingkungan, dan tata kelola perusahan (ESG) dengan baik (Bennett \& Iqbal, 2013). Perusahaan-perusahaan yang menerapkan konsep tersebut di Indonesia terdaftar pada Indeks SRI KEHATI. Perusahaan yang masuk pada daftar indeks SRI KEHATI memiliki reputasi yang baik sehingga dapat memiliki bank-firm relationships dan kinerja yang lebih baik.

\section{KAJIAN LITERATUR}

\subsection{Landasan Teori}

Pada awalnya, bank dan lembaga keuangan non-bank hanya perantara keuangan yaitu mengumpulkan deposito dan meminjamkan kepada debitor (Werner, 2016). Selanjutnya, terdapat perkembangan pada financial intermediate theory yang menjelaskan bahwa adanya peran lain pada bank sebagai lembaga keuangan. Teori intermediasi keuangan (finance intermediate theory) menyatakan bahwa peran bank tidak hanya sebagai penyedia pinjaman perusahan saja, tetapi juga dapat berperan sebagai mekanisme kontrol dan tata kelola perusahaan (Ongena \& Yu, 2017; 
Zemzem, Guesmi \& Ftouhi, 2017). Kondisi tersebut mengarahkan bank dapat berperan ganda yaitu sebagai kreditur dan sebagai pemegang saham yang dapat mengendalikan dan mengawasi (Firdausi \& Sulung, 2019; Ghosh, 2015). Oleh karena itu, bank sebagai pemberi pinjaman dana dapat membentuk bank-firm relationship dalam rangka memantau dan mengawasi perusahaan peminjam.

Hubungan bank-firm relationship (BFR) terhadap kinerja perusahaan dapat dijelaskan dengan agency cost theory. Menurut agency cost theory, manajer (agen) perusahaan akan menjalankan tugasnya atas instruksi dari pemegang saham (prinsipal) (Dawar, 2014; Huang, Zhang \& Zhao, 2018). Ketika manajer tidak dapat menjalankan tugasnya untuk kepentingan terbaik pemegang saham, karena ingin memaksimalkan keuntungannya, masalah keagenan dapat terjadi (Dawar, 2014; Ferrell, Liang \& Renneboog, 2016; Jensen \& Meckling, 1976). Oleh karena itu, menerbitkan hutang dapat menurunkan biaya agensi dan mempengaruhi kinerja perusahaan dengan mendorong manajer untuk bertindak demi kepentingan terbaik pemegang saham (Dawar, 2014; Jensen \& Meckling, 1976). Penggunaan leverage dapat mengurangi biaya agensi dengan cara mendorong manajer untuk bertindak lebih untuk kepentingan pemegang saham, sehingga menaikkan leverage dapat mengurangi biaya agensi dan memiliki efek positif pada profitabilitas dan kinerja perusahaan (Dawar, 2014; Jensen \& Meckling, 1976).

Bank-firm relationship (BFR) dapat mengurangi adanya informasi yang asimetris dan masalah agensi ketika informasi internal perusahaan sudah diserahkan ke bank. Adanya informasi tersebut dapat digunakan bank untuk memantau perusahaan. Dengan kata lain, BFR terbentuk ketika bank dapat memperoleh informasi yang lebih luas dari perusahaan karena konsekuensi dari hutang yang diberikan kepada perusahaan (Aristei \& Gallo, 2017; Gama \& Auken, 2014). Pinjaman bank juga memungkinkan perusahaan membangun reputasi yang baik, sehingga dapat mengurangi biaya modal dan meningkatkan ketersediaan kredit. BFR juga dapat berfungsi sebagai sinyal yang baik untuk investasi pemegang saham yang memaksimalkan kekayaan karena adanya ketersediaan kas untuk ekspansi perusahaan (Cui, Cuong \& Shimizu, 2019).

\subsection{Pengembangan Hipotesis}

Menurut Fok et al. (2004), bank-firm relationship (BFR) memberikan manfaat bagi perusahaan yaitu dapat meningkatkan kinerja keuangan karena dapat mengurangi biaya informasi, mengurangi biaya pinjaman, dan menghindari bocornya informasi internal perusahaan dari pesaing. Selain itu, pinjaman bank memungkinkan perusahaan untuk membangun reputasi yang baik. Adanya pinjaman perusahaan dapat meningkatkan ketersediaan kredit dan berdampak pada peningkatan pendanaan perusahaan yang dapat berdampak langsung pada kinerja perusahaan (Angori et al., 2019). Selanjutnya BFR juga dapat menimbulkan biaya pinjaman perusahaan yang menurun sejalan dengan dengan kekuatan bank relationship yang terjalin (Stein, 2015). Namun hal tersebut bergantung pada seberapa besar persentase hutang bank dari total hutang perusahaan (bank loan ratio/ BLR) (Fok et al., 2004).

Adanya peran ganda bank dalam konteks bank-firm relationship, menyebabkan bank dapat melakukan pengawasan dan pemantauan terhadap perusahaan, sehingga dapat mengurangi konflik agensi pada agency cost theory dan dapat meningkatkan kinerja perusahaan (Cucculelli, Peruzzi \& Zazzaro, 2019; Jadiyappa et al., 2020; Zemzem et al., 2017). Gambini \& Zazzaro (2013) menemukan bahwa perusahaan yang melakukan bank-relationships dapat meningkatkan size perusahaan. Petersen \& Rajan (1994) menyatakan bahwa adanya hubungan bank-firm 
relationships berpengaruh pada pinjaman melalui infomasi tentang penjualan dengan memantau arus kas. Selain itu, dengan bank melakukan diversifikasi produk pinjaman dan memberikan biaya tetap pada perusahaan dapat menghasilkan banyaknya informasi tentang perusahaan. Kondisi tersebut dapat mengurangi biaya bank dan menjadi keuntungan juga untuk perusahaan, yaitu adanya peningkatan ketersediaan dana perusahaan. Aristei \& Gallo (2017) menjelaskan hubungan perusahaan dengan bank secara signifikan dapat berpengaruh pada kondisi keuangan eksternal, kinerja perusahaan dan profitabilitas bank.

Pada beberapa penelitian terdahulu menunjukkan bahwa bank-relationships berhubungan dengan kinerja perusahaan (Cui et al., 2019; Dass \& Massa, 2011; Tsapin, 2017; Zemzem et al., 2017). Zemzem et al. (2017) menemukan bahwa bahwa keberadaan bank dalam suatu perusahaan, sebagai kreditor atau pemegang saham, berhubungan positif dengan kinerja perusahaan. Selain itu, Tsapin (2017) dan Cui et al. (2019) menemukan bahwa perusahaan-perusahaan yang melakukan multiple bank-firm relationships cenderung memiliki lebih banyak cadangan kas. Hubungan tersebut penting dilakukan untuk membantu perusahaan menyelesaikan konflik keagenan dan memfasilitasi pengurangan kendala keuangan perusahaan. Dass \& Massa (2011) menemukan bahwa hubungan yang lebih kuat, dengan mendorong pemantauan yang lebih baik, meningkatkan tata kelola perusahaan peminjam. Houston \& James (1996) menemukan bahwa perusahaan yang mempunyai pinjaman dari banyak bank berhubungan positif dengan peluang pertumbuhan perusahaan. Hal tersebut berkebalikan dengan perusahaan yang hanya melakukan single-bank relationship.

Selain ditinjau dari banyaknya bank-relationships, perkembangan penelitian empiris juga mengkaji hubungan perusahaan dengan bank asing dan domestik. Kehadiran bank asing dan domestik mempunyai dampak yang berbeda bagi perusahaan. Munculnya asimetri informasi menjadi alasan perusahaan dalam membangun hubungan dengan jenis kepemilikan yang berbeda yaitu bank asing atau domestik (Bermpei, Kalyvas, Neri \& Russo, 2019; Yin \& Matthews, 2017). Bonin, Hasan \& Wachtel (2005) menemukan bahwa biaya yang diberikan oleh bank asing lebih rendah daripada bank domestik. Selain itu, bank asing sering memberikan layanan yang lebih baik. Bank asing lebih menguntungkan daripada bank domestik ketika bank tersebut beroperasi di negara yang sistem perbankannya kurang kompetitif (Chen \& Liao, 2011).

Selanjutnya Chen \& Liao (2011) menjelaskan bank asing biasanya memberikan keuntungan kepada peminjam di negara tempat beroperasi berupa suku bunga yang lebih rendah daripada bank domestik. Fok et al. (2004) menyatakan bahwa bank asing cenderung memberikan pinjaman yang berulang untuk mengumpulkan informasi tentang perusahaan yang dipinjami. Penelitian lainnya yang dilakukan Jeon, Olivero \& Wu (2011) menemukan bahwa penetrasi bank asing dan hubungan persaingan perbankan yang positif. Fok et al. (2004) menyatakan bahwa perbedaan mendasar antara pinjaman bank asing dan bank domestik terletak pada transaksi loans relationship. Lin (2011) menemukan bahwa bank asing cenderung memberikan pinjaman jangka panjang kepada perusahaan daripada bank domestik. Manfaat dari transaksi loans relationship dapat terasa bagi bank yang posisinya sebagai kreditur, yaitu dalam mengumpulkan informasi mengenai kinerja perusahaan selama periode pinjaman tersebut.

Pada penelitian Fok et al. (2004) menemukan bahwa foreign-bank relationship berpengaruh terhadap kinerja perusahaan. Giannetti \& Ongena (2009) menjelaskan bahwa pinjaman asing menstimulasi pertumbuhan penjualan perusahaan, aset, dan penggunaan utang finansial. Selain itu, perusahaan-perusahaan yang berusia muda diuntungkan dari kehadiran bank 
asing daripada hanya mengandalkan bank domestik. Hubungan perusahaan dengan bank asing dapat membantu mengurangi masalah pinjaman dan meningkatkan alokasi modal.

Meskipun teori agency cost theory dan penelitian empiris sebelumnya menunjukkan bahwa bank relatioships memiliki pengaruh pada kinerja perusahaan, ternyata hubungan tersebut dapat bersifat kausalitas terbalik atau simultan. Kinerja perusahaan bisa saja berpengaruh terhadap bank relationships. Detragiache et al. (2000) menemukan bahwa perusahaan dengan kinerja yang lebih baik dan mempunyai peluang pertumbuhan yang lebih tinggi menyukai melakukan multiplebank relationship sehingga dapat mengurangi risiko likuiditas. Aristei \& Gallo (2017) menjelaskan perusahaan yang lebih tergantung pada pembiayaan eksternal cenderung melakukan multiple-bank relationship. Perusahaan yang ingin mendiversifikasi sumber pembiayaan eksternal biasanya menjalin hubungan dengan banyak bank. Temuan penelitian Detragiache et al. (2000) dan Aristei \& Gallo (2017) menjadi penting untuk diteliti khususnya pada konteks perusahaan-perusahaan socially responsible investment (SRI) di Indonesia.

Penelitian Aristei \& Gallo (2017) menemukan bahwa perusahaan besar, lebih tua, dan aktif secara internasional biasanya cenderung memiliki hubungan baik dengan bank asing. Bank asing mampu menyediakan layanan perbankan yang lebih kompleks yang penting bagi perusahaan untuk mengakses pasar asing. Kondisi tersebut memudahkan perusahaan-perusahaan yang berkinerja baik dan mempunyai bisnis internasional memiliki kecenderungan untuk melakukan hubungan dengan bank asing. Penelitian Guiso \& Minetti (2010) menemukan bahwa perusahaan-perusahaan dengan aset yang lebih bernilai dan lebih homogen membedakan pinjaman dengan lebih tajam pada kreditor yang terkonsentrasi. Selain itu, diferensiasi pinjaman positif terkait dengan transparansi informasi perusahaan. Berdasarkan uraian sebelumnya, maka pada penelitian ini, hipotesis pertama adalah bank-firm relationship berpengaruh terhadap kinerja perusahaan Socially Responsible Investment (SRI) di Indonesia dan hipotesis kedua adalah kinerja perusahaan Socially Responsible Investment (SRI) berpengaruh terhadap bank-firm relationship di Indonesia

\section{METODE PENELITIAN}

Berdasarkan tujuan penelitian ini, sampel yang digunakan adalah perusahaan-perusahaan non-keuangan yang terdaftar di indeks SRI-KEHATI pada tahun 2012 - 2016. Indeks tersebut dibentuk atas inisiasi Yayasan Keanekaragaman Hayati (KEHATI). Perusahaan yang terdaftar di Bursa Efek Indonesia dievaluasi setiap 2 (dua) periode dalam setahun pada bulan April dan Oktober. Kriteria screening berdasarkan kinerja sosial yang meliputi aspek tata kelola perusahaan, keterlibatan masyarakat, sumberdaya manusia, hak asasi manusia, kepedulian terhadap lingkungan, dan perilaku bisnis dengan etika bisnis yang diterima di tingkat internasional. Selain itu dari aspek keuangan perusahaan harus memiliki kapitalisasi pasar dan total aset yang lebih dari 1 trilliun rupiah, free float rate lebih dari $10 \%$, serta rasio harga saham terhadap laba positif.

Selanjutnya dipilih 25 (dua puluh lima) perusahaan dengan penilaian sosial dan keuangan tertinggi yang masuk sebagai konstituen indeks SRI-KEHATI. Pada praktiknya, daftar konstituen SRI-KEHATI mengalami penyesuaian dari tahun ke tahun. Atas dasar tersebut, penelitian ini menerapkan purposive sampling dengan kriteria perusahaan pada indeks SRI-KEHATI yang secara konsisten selalu tercatat pada indeks tersebut selama 5 (lima) tahun dan bukan perusahaan keuangan (non-keuangan). Dari kriteria tersebut diperoleh 11 perusahaan dengan total 55 observasi. 
Tabel 1. Definisi operasional variabel

\begin{tabular}{|c|c|}
\hline Variabel Utama & Definisi \\
\hline ROA & $\begin{array}{l}\text { Indikator kinerja perusahaan yang diukur dengan rasio laba setelah pajak terhadap total } \\
\text { aset (Fok et al., 2004; Ghosh, 2016). }\end{array}$ \\
\hline MULTIPLE & $\begin{array}{l}\text { Indikator bank-firm relationship yang diukur dengan dummy bernilai } 1 \text { jika perusahaan } \\
\text { memilih hubungan dengan lebih dari satu bank (Brown \& Hoffmann, 2016; Fok et al., } \\
\text { 2004; Ghosh, 2016). }\end{array}$ \\
\hline LNUM & $\begin{array}{l}\text { Indikator bank-firm relationship yang diukur dengan log natural dari jumlah bank yang } \\
\text { memiliki relasi dengan perusahaan (Fok et al., 2004). }\end{array}$ \\
\hline LFNUM & $\begin{array}{l}\text { Indikator bank-firm relationship yang diukur dengan log natural dari jumlah bank asing } \\
\text { yang memiliki relasi dengan perusahaan (Fok et al., 2004). }\end{array}$ \\
\hline LDNUM & $\begin{array}{l}\text { Indikator bank-firm relationship yang diukur dengan log natural dari jumlah bank } \\
\text { domestik yang memiliki relasi dengan perusahaan (Fok et al., 2004). }\end{array}$ \\
\hline LOAN & $\begin{array}{l}\text { Rasio utang bank terhadap total liabilitas yang sering disebut bank-loan ratio (Fok et } \\
\text { al., 2004). }\end{array}$ \\
\hline \multicolumn{2}{|l|}{ Variabel Kontrol } \\
\hline SIZE & $\begin{array}{l}\text { Indikator ukuran perusahaan yang diukur dengan natural logaritma dari total aset } \\
\text { perusahaan (Fok et al., 2004). Perusahaan besar memiliki kekuatan pasar yang besar dan } \\
\text { akses modal yang lebih baik sehingga berpengaruh positif terhadap kinerja. }\end{array}$ \\
\hline DEP & $\begin{array}{l}\text { Indikator peluang pertumbuhan yang diukur dengan rasio dari beban depresiasi terhadap } \\
\text { total aset (Fok et al., 2004). Semakin tinggi beban depresiasi aset, semakin banyak aset } \\
\text { berwujud yang miliki perusahaan sehingga menurunkan peluang pertumbuhan. } \\
\text { Selanjutnya hal tersebut akan menurunkan profitabilitas jangka panjang. }\end{array}$ \\
\hline LEV & $\begin{array}{l}\text { Indikator struktur modal yang diukur dengan rasio hutang terhadap total aset (Fok et al., } \\
\text { 2004; Ghosh, 2016). Perusahaan yang memiliki rasio hutang yang tinggi berpotensi } \\
\text { untuk mengalami financial distress. Hal tersebut akan mengurangi kinerja perusahaan. }\end{array}$ \\
\hline ICR & $\begin{array}{l}\text { Indikator tingkat likuiditas yang diukur dengan rasio EBIT terhadap pengeluaran bunga } \\
\text { hutang (Fok et al., 2004). ICR digunakan untuk mengukur kemampuan perusahaan } \\
\text { dalam melunasi kewajiban jangka pendek diukur dari seberapa besar laba yang dapat } \\
\text { digunakan untuk membayar bunga bank (ICR). Perusahaan dengan ICR yang tinggi } \\
\text { memiliki risiko likuiditas yang rendah sehingga semakin mudah mendapatkan pinjaman } \\
\text { dari bank. }\end{array}$ \\
\hline
\end{tabular}

Tabel 1 menjelaskan definisi operasional dari semua variabel yang digunakan sebagai indikator. Bank-firm relationship diukur dengan menggunakan lima variabel yakni MULTIPLE, LNUM, LFNUM, LDNUM dan LOAN sedangkan kinerja perusahaan diukur dengan ROA. Hubungan simultan antara bank-firm relationship dan kinerja perusahaan dikontrol dengan SIZE, DEP, LEV, dan ICR. Model penelitian pada pengujian hubungan simultan antara bank-firm relationship dan kinerja perusahaan dapat dilihat pada Gambar 1.

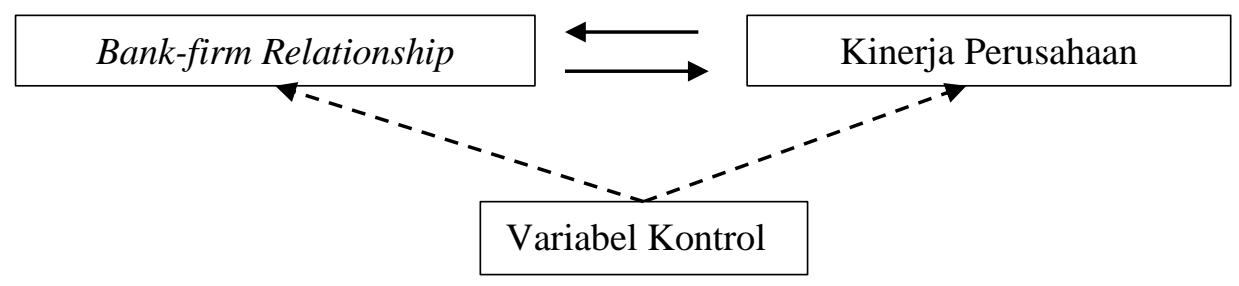

\section{Gambar 1. Model Penelitian}

Metode analisis yang digunakan pada penelitian ini adalah two-stage least squares (2SLS) untuk mengatasi masalah endogenitas pada persamaan simultan (Greene, 2018). Hal yang membedakan dengan metode regresi pada umumnya adalah penggunaan variabel instrumen (VI). Variabel tersebut diasumsikan tidak berkorelasi dengan error term namun harus berkorelasi dengan variabel endogen. Dalam konteks penelitian ini, variabel endogen meliputi indikator bank- 
firm relationship dan kinerja. Sementara itu penentuan variabel instrumen harus berdasarkan teori atau penelitian sebelumnya (Wooldridge, 2016). Mengacu pada studi empiris oleh Fok et al. (2004) dan López-Espín, Vidal \& Giménez (2012), DEP dan ICR diberlakukan sebagai variabel instrumen masing-masing untuk kinerja dan bank-firm relationship (BFR). Persamaan (1) dan (2) menunjukkan hubungan kausalitas antara BFR yang diukur dengan MULTIPLE, LNUM, LFNUM, LDNUM dan BLR serta kinerja yang diukur dengan ROA.

$$
\begin{aligned}
& \mathrm{ROA}_{i t}=\alpha_{0}+\alpha_{1} \mathrm{BFR}_{i t}+\alpha_{2} \mathrm{SIZE}_{i t}+\alpha_{3} \mathrm{DEP}_{i t}+\alpha_{4} \mathrm{LEV}_{i t}+\varepsilon_{\mathrm{it}} \\
& B F R_{i t}=\alpha_{0}+\alpha_{1} \mathrm{ROA}_{i t}+\alpha_{2} \mathrm{SIZE}_{i t}+\alpha_{3} \mathrm{LEV}_{i t}+\alpha_{4} \mathrm{ICR}_{i t}+\varepsilon_{\mathrm{it}}
\end{aligned}
$$

Pada persamaan 1 dan 2, DEP hanya mempengaruhi ROA sedangkan ICR hanya mempengaruhi BFR. Menurut Fok et al. (2004), nilai ICR menggambarkan likuiditas dimana perusahaan yang likuid akan bergantung pada lebih sedikit bank. Selanjutnya semakin tinggi rasio depresiasi akan menyebabkan semakin rendah peluang pertumbuhan dan kinerja perusahaan (Fok et al., 2004). Sementara SIZE dan LEV pada model 2SLS berperan sebagai variabel eksogen. Langka pertama adalah melakukan first-stage regression sebagai berikut:

$\mathrm{ROA}_{i t}=\alpha_{0}+\alpha_{1} \mathrm{SIZE}_{i t}+\alpha_{2} \mathrm{DEP}_{i t}+\alpha_{3} \mathrm{LEV}_{i t}+\varepsilon_{\mathrm{it}}$

$B F R_{i t}=\alpha_{0}+\alpha_{1} \operatorname{SIZE}_{i t}+\alpha_{2} \mathrm{LEV}_{i t}+\alpha_{3} \mathrm{ICR}_{i t}+\varepsilon_{i \mathrm{t}}$

Selanjutnya akan didapat fitted value $\widehat{\mathrm{ROA}}_{i t}$ dan $\widehat{\mathrm{BFR}}_{i t}$ dan dilakukan second-stage regression sebagai berikut:

$\mathrm{ROA}_{i t}=\alpha_{0}+\alpha_{1} \widehat{B F R}_{i t}+\alpha_{2} \mathrm{SIZE}_{i t}+\alpha_{3} \mathrm{LEV}_{i t}+\varepsilon_{\mathrm{it}}$

$B F R_{i t}=\alpha_{0}+\alpha_{1} \widehat{\operatorname{ROA}}_{i t}+\alpha_{2} \operatorname{SIZE}_{i t}+\alpha_{3} \operatorname{LEV}_{i t}+\varepsilon_{i t}$

Persamaan (1) - (6) berlaku untuk semua indikator BFR. Hubungan simultan terdukung jika nilai $\alpha_{1}$ dipersamaan ROA dan BFR signifikan.

\section{HASIL DAN PEMBAHASAN}

Pada penelitian ini bertujuan untuk menguji hubungan simultan bank-firm relationships terhadap kinerja perusahaan yang menerapkan socially responsible investment (SRI) di Indonesia. Suatu perusahaan disebut socially responsible jika mengutamakan 3 aspek yaitu lingkungan (E), sosial (S), dan tata kelola (G). Tabel 2 menggambarkan statistik deskriptif variabel-variabel pada penelitian ini.

Kinerja keuangan dapat mengukur bagaimana perusahaan menggunakan aset perusahaan untuk menghasilkan pendapatan, sehingga pada beberapa penelitian menggunakan return on asset (ROA) sebagai indikatornya (Fok et al., 2004; Paul, 2017). Berdasarkan tabel 2 dapat dijelaskan bahwa rerata ROA pada perusahaan SRI-KEHATI sebesar 9,88 persen dengan nilai tertinggi 23,42 persen. Hal tersebut menunjukkan bahwa perusahaan SRI-KEHATI memiliki kinerja baik dari aspek sosial, lingkungan, dan tata kelola serta keuangan. 
Tabel 2. Statistik Deskriptif

\begin{tabular}{lllll}
\hline Variabel & Mean & Standar Deviasi & Min. & Maks. \\
\hline ROA & 9,88 & 5,58 & 1,57 & 23,42 \\
MULTIPLE & 0.58 & 0.50 & 0 & 1 \\
LOAN & 18,26 & 21,24 & 0,48 & 84,26 \\
NUM & 8,54 & 4,93 & 1 & 20 \\
FNUM & 3,65 & 3,52 & 0 & 13 \\
DNUM & 4,89 & 4,24 & 1 & 16 \\
SIZE & 14.45 & 13.72 & 5.33 & 26.29 \\
DEP & 13,43 & 23,42 & 0,78 & 44,13 \\
LEV & 14,58 & 11,04 & 0,36 & 99 \\
ICR & 17,72 & 23,55 & 0,93 & \\
\hline
\end{tabular}

Keterangan:

ROA $=$ return on asset $(\%) ;$ Multiple $=$ variabel dummy $(0=$ single-bank relationships $; 1=$ multiple-bank relationships); LOAN = bank loan ratio (\%); NUM = banyaknya bank relationships; FNUM = banyak bank relationships dengan bank asing/ foreign bank; DNUM = banyak bank relationships dengan bank domestik/ domestic bank; SIZE = natural logaritma dari total aset perusahaan; DEP = rasio dari pengeluaran depresiasi terhadap total aset $(\%)$; LEV = rasio hutang terhadap total aset $(\%)$; ICR = rasio EBIT terhadap pengeluaran bunga hutang (\%)

Berkaitan dengan bank relationship, dapat dijelaskan bahwa rerata multiple bank relationships adalah 0,58 . Selain itu, pada jumlah bank relationship (NUM) menunjukkan bahwa rata-rata perusahaan SRI di Indonesia berelasi dengan 8 bank sementara jumlah terbanyak yakni 20. Hal tersebut menunjukkan bahwa perusahaan-perusahaan yang terdaftar pada indeks SRIKEHATI mempunyai relasi yang baik dengan sektor perbankan. Bonfim, Dai \& Franco (2018) menemukan bahwa perusahaan yang berhubungan dengan multi-bank dapat mengurangi informasi yang asimetris dalam proses pengajuan pinjaman baru. Selain itu, Belaid, Boussaada \& Belguith (2017) yang menjelaskan adanya bank-firm relationships dapat meningkatkan kualitas portfolio kredit bank. Dengan demikian, relasi tersebut dapat mengurangi risiko likuiditas perusahaan dan risiko kredit pada bank (Bennouri, Falconieri \& Kooli, 2017; Detragiache et al., 2000; Shikimi, 2013).

Namun, perusahaan-perusahaan yang melakukan socially responsible investment (SRI) cenderung lebih banyak berelasi dengan bank domestik daripada bank asing. Hal tersebut ditunjukkan dengan rerata relasi bank domestik yang lebih besar daripada bank asing. Sejalan dengan penelitian yang dilakukan Fok et al. (2004) yang menjelaskan bahwa bank domestik cenderung gencar dalam memberikan pinjaman kepada perusahaan di negara tersebut daripada bank asing. Opportunity cost yang tinggi pada bank-bank domestik menjadi alasan mengapa mereka lebih agresif dalam menyalurkan kredit. 
Tabel 3. Hasil analisis hubungan simultan bank asing, bank domestik, banyaknya bank dan bank loan ratio terhadap kinerja perusahaan

\begin{tabular}{|c|c|c|c|c|c|c|c|c|}
\hline \multirow[b]{2}{*}{ Variabel } & \multicolumn{2}{|c|}{$\begin{array}{c}\text { Model 1 } \\
(\mathrm{N}=55)\end{array}$} & \multicolumn{2}{|c|}{$\begin{array}{c}\text { Model } 2 \\
(\mathrm{~N}=55)\end{array}$} & \multicolumn{2}{|c|}{$\begin{array}{c}\text { Model 3 } \\
(\mathrm{N}=55)\end{array}$} & \multicolumn{2}{|c|}{$\begin{array}{c}\text { Model } 4 \\
(\mathrm{~N}=55)\end{array}$} \\
\hline & ROA & LNUM & ROA & LFNUM & ROA & LDNUM & ROA & LOAN \\
\hline INTERCEPT & $\begin{array}{l}-0.141 \\
(-0.60)\end{array}$ & $\begin{array}{l}-2.098 \\
(-0.63)\end{array}$ & $\begin{array}{l}-0.034 \\
(-0.21)\end{array}$ & $\begin{array}{l}-5.354 \\
(-0.33)\end{array}$ & $\begin{array}{l}0.431 \\
(1.26)\end{array}$ & $\begin{array}{l}-1.546 \\
(-0.25)\end{array}$ & $\begin{array}{l}0.236 \\
(1.84)\end{array}$ & $\begin{array}{l}-0.639 \\
(-0.17)\end{array}$ \\
\hline ROA & & $\begin{array}{l}38.94 \\
(1.09)\end{array}$ & & $\begin{array}{l}67.44 \\
(0.36)\end{array}$ & & $\begin{array}{l}30.17 \\
(0.42)\end{array}$ & & $\begin{array}{l}9.142 \\
(0.21)\end{array}$ \\
\hline LNUM & $\begin{array}{l}0.230 \\
(1.26)\end{array}$ & & & & & & & \\
\hline LFNUM & & & $\begin{array}{l}0.176 \\
(1.37)\end{array}$ & & & & & \\
\hline LDNUM & & & & & $\begin{array}{l}-0.329 \\
(-0.89)\end{array}$ & & & \\
\hline BLR & & & & & & & $\begin{array}{l}-0.941 \\
(-1.19)\end{array}$ & \\
\hline DEP & $\begin{array}{l}0.330 \\
(0.97)\end{array}$ & & $\begin{array}{l}0.258 \\
(0.90)\end{array}$ & & $\begin{array}{l}-0.338 \\
(-0.82)\end{array}$ & & & \\
\hline SIZE & $\begin{array}{l}-0.0075 \\
(-1.29)\end{array}$ & $\begin{array}{l}0.0214 \\
(0.62)\end{array}$ & $\begin{array}{l}-0.005 \\
(-1.38)\end{array}$ & $\begin{array}{l}0.0096 \\
(0.11)\end{array}$ & $\begin{array}{l}-0.0244 \\
(-0.19)\end{array}$ & $\begin{array}{l}0.0066 \\
(0.14)\end{array}$ & $\begin{array}{l}0.0051 \\
(0.76)\end{array}$ & $\begin{array}{l}0.005 \\
(0.34)\end{array}$ \\
\hline LEVERAGE & $\begin{array}{l}-0.701 * * \\
(-2.17)\end{array}$ & $\begin{array}{l}5.406 \\
(1.31)\end{array}$ & $\begin{array}{l}-0.227 \\
(-1.27)\end{array}$ & $\begin{array}{l}6.333 \\
(0.54)\end{array}$ & $\begin{array}{l}0.277 \\
(0.44)\end{array}$ & $\begin{array}{l}3.699 \\
(0.51)\end{array}$ & $\begin{array}{l}-0.066 \\
(-0.23)\end{array}$ & $\begin{array}{l}0.892 \\
(0.19)\end{array}$ \\
\hline ICR & & $\begin{array}{l}-0.055 \\
(-0.93)\end{array}$ & & $\begin{array}{l}-0.0876 \\
(-0.42)\end{array}$ & & $\begin{array}{l}-0.0309 \\
(-0.46)\end{array}$ & & $\begin{array}{l}-0.013 \\
(-0.32)\end{array}$ \\
\hline
\end{tabular}

t-statistics

$* \operatorname{sig} .10 \%$; ** sig. $5 \%$; *** sig. $1 \%$

Keterangan:

$\mathrm{ROA}=$ return on asset $(\%) ;$ BLR = bank loan ratio $(\%) ;$ LNUM = logaritma natural banyaknya bank relationships; LFNUM = logaritma natural banyak bank relationships dengan bank asing; LDNUM = logaritma natural banyak bank relationships dengan bank domestik; SIZE = natural logaritma dari total aset perusahaan; DEP = rasio dari pengeluaran depresiasi terhadap total aset (\%); LEVERAGE = rasio hutang terhadap total aset $(\%) ; \mathrm{ICR}=$ rasio EBIT terhadap pengeluaran bunga hutang $(\%)$

Fok et al. (2004) menggunakan bank loan ratio (LOAN) karena rasio tersebut dapat menghitung trade-off biaya dan manfaat perusahaan ketika melakukan bank-firm relationships. Nilai rerata LOAN adalah 18,26 persen yang menunjukkan bahwa penggunaan hutang bank terhadap keseluruhan hutang perusahaan masih tergolong kecil. Hal tersebut menunjukkan bahwa perusahaan SRI-KEHATI cenderung mengurangi penggunaan hutang bank. Selain pada rasio debtto-total asset (LEV) cenderung kecil dengan rerata 14,58 persen dan kisaran dari 0,36 hingga 44,11 persen. Hal tersebut mengindikasikan nilai total aset perusahaan SRI-KEHATI cenderung lebih besar daripada total hutang.

Tabel 3 melaporkan hasil regresi 2SLS. Jika BFR diukur dengan LNUM, LFNUM, LDNUM, dan LOAN maka hubungan kausalitas tidak terdukung. Hanya LEV yang signifikan berpengaruh terhadap kinerja. Sementara itu, pada tabel 4, MULTIPLE berpengaruh positif dan signifikan terhadap kinerja perusahaan. Hal tersebut menunjukkan bahwa semakin banyak jumlah bank yang memberi pinjaman, semakin tinggi kinerja keuangan. Hasil yang sama juga terjadi pada penelitian Zemzem et al. (2017) menemukan bahwa bahwa keberadaan bank dalam suatu perusahaan, sebagai kreditor atau pemegang saham, berhubungan positif dengan kinerja perusahaan. Selain itu, hubungan yang terjalin dengan baik antara perusahaan dan bank dapat mengurangi kendala kredit secara signifikan (Angori et al., 2019; Kysucky \& Norden, 2015). 
Dengan demikian, semakin banyaknya sumber pendanaan, semakin rendah biaya modal (cost of capital) perusahaan, semakin tinggi kinerja perusahaan (Zemzem et al., 2017). Pengaruh balik (reverse causal) terdukung jika relasi bank-perusahaan diukur dengan jumlah bank. Hal tersebut menunjukkan bahwa semakin tinggi kinerja keuangan akan mempermudah perusahaan untuk mengakses pendanaan dari banyak bank.

Tabel 4. Hasil estimasi simultan pengaruh multiple-bank relationship terhadap kinerja perusahaan

\begin{tabular}{lcc} 
& \multicolumn{3}{c}{$\begin{array}{c}\text { Model 5 } \\
\text { (N = 55) }\end{array}$} \\
\cline { 2 - 3 } & Rariabel & $\begin{array}{c}\text { MULTIPLE } \\
\text { (Probit) }\end{array}$ \\
\hline INTERCEPT & $(\mathbf{O L S})$ & $-174.8^{*}$ \\
& -0.0393 & $(-2.35)$ \\
MULTIPLE & $(-0.88)$ & \\
ROA & $0.446^{* * *}$ & $1213.3^{* *}$ \\
& $(4.73)$ & $(2.31)$ \\
SIZE & & $1.063^{* *}$ \\
& & $(3.29)$ \\
DEP & $-0.00328^{* *}$ & \\
& $(-3.01)$ & $253.7^{*}$ \\
LEVERAGE & -0.0418 & $(2.42)$ \\
& $(-0.83)$ & -0.00113 \\
ICR & $-0.389^{* * *}$ & $(-0.02)$ \\
& $(-5.05)$ & \\
\hline
\end{tabular}

t-statistics

$* \operatorname{sig} .10 \% ; * *$ sig. $5 \%$;** sig. $1 \%$

Keterangan:

$\mathrm{ROA}=$ return on asset $(\%)$; Multiple $=$ variabel dummy $(0=$ single-bank relationships; $1=$ multiple -

bank relationships); SIZE = natural logaritma dari total aset perusahaan; DEP = rasio dari pengeluaran

depresiasi terhadap total aset $(\%)$; LEVERAGE = rasio hutang terhadap total aset $(\%)$; ICR = rasio

EBIT terhadap pengeluaran bunga hutang $(\%)$

Hasil ini mendukung temuan Refait-Alexandre \& Serve (2020) bahwa perusahaan besar, memiliki yang kinerja baik dan inovatif cenderung akan melakukan hubungan dengan banyak bank. Sama dengan Aristei \& Gallo (2017), perusahaan yang lebih bergantung pada pembiayaan eksternal cenderung menggunakan menerapkan multiple-bank relationship sebagai strategi untuk mendiversifikasi sumber pendanaan eksternal dan mengurangi kendala kredit.

Secara keseluruhan, hasil pada penelitian ini berkaitan dengan agency cost theory yang menunjukkan bahwa bank-firm relationship dapat mengurangi agency problem yaitu salah satunya dengan melakukan hubungan multiple-bank relationship untuk melakukan diversifikasi pinjaman dan mengurangi kegagalan proyek yang dilakukan (Zemzem et al., 2017). Selain itu, dalam meminimalkan biaya agensi, bank berperan sebagai pemantau dan dapat memperoleh informasi non-keuangan lainnya tentang perusahaan peminjam melalui pemantauan tersebut (French, Yan \& Yasuda, 2019). Selanjutnya, perusahaan yang mempunyai hubungan dengan banyak bank akan mempertahankan reputasi baiknya untuk mendapatkan manfaat saat pinjaman selanjutnya dan bank juga dapat dengan mudah untuk memantau perusahaan (Fok et al., 2004; Zemzem et al., 2017).

Hasil penelitian ini juga terkonfirmasi dari nilai rasio LOAN perusahaan SRI-KEHATI di Indonesia yang bervariasi antara 0,48 - 84,26 persen. Berdasarkan data tersebut beberapa perusahaan dengan kinerja yang cukup baik masih bergantung dengan pinjaman bank. Pada posisi 
ini, manfaat dari kemudahan akses terhadap kredit perbankan berkontribusi besar terhadap tingkat pertumbuhan perusahaan (Gambini \& Zazzaro, 2013; Takahashi, 2014).

\section{SIMPULAN DAN REKOMENDASI}

Penelitian ini bertujuan untuk menguji apakah terhadap hubungan simultan bank-firm relationships dan kinerja perusahaan. Hal yang berbeda dengan penelitian terdahulu, penelitian ini menggunakan perusahaan-perusahaan yang menerapkan Socially Responsible Investment (SRI) di Indonesia. Adapun perusahaan-perusahaan tersebut terdaftar pada indeks SRI-KEHATI. Data yang digunakan pada penelitian ini merupakan data panel dengan spesifikasi terdapat 11 perusahaan pada periode penelitian tahun 2012-2016. Metode yang digunakan pada penelitian ini menggunakan 2SLS.

Hasil penelitian menunjukkan terdapat pengaruh multiple bank relationship yang positif dan signifikan terhadap kinerja. Hal tersebut menunjukkan bahwa keberadaan multiple-bank relationship pada perusahaan-perusahaan Socially Responsible Investment (SRI) dapat meningkatkan kinerja perusahaan. Selain itu, hasil estimasi simultan menunjukkan bahwa perusahaan yang mempunyai kinerja yang semakin baik cenderung akan melakukan multiple bank relationship. Perusahaan-perusahaan cenderung menggunakan multiple-bank relationship karena melakukan diversifikasi sumber pendanaan eksternal, mengurangi kendala kredit dan mengurangi kegagalan strategi.

Implikasi pada penelitian ini dapat digunakan pada manajer perusahaan terkait manfaat pada bank-firm relationship. Pada penelitian ini menunjukkan bahwa relasi dengan banyak bank dapat meningkatkan kinerja, dan sebaliknya. Hal tersebut dapat digunakan sebagai pertimbangan manajer untuk melakukan diversifikasi pinjaman dengan banyak bank karena dapat menambah ketersediaan dana perusahaan, mengurangi kegagalan proyek, dan mengurangi biaya pinjaman. Selain itu, berdasarkan agency cost theory, semakin meningkatnya leverage perusahaan dapat mengurangi biaya agensi. Pada sisi perbankan, implikasi penelitian adalah bank perlu melakukan hubungan dengan perusahaan untuk mengurangi adanya informasi yang asimetris dan moral hazard pada perusahaan peminjam dengan melakukan pengawasan dan monitoring perusahaan peminjam.

Pada pengujian hubungan simultan BFR terhadap kinerja, selain multiple-bank relationship menunjukkan hasil yang tidak signifikan baik dengan bank domestik maupun bank asing. Hasil yang tidak signifikan pada estimasi tersebut dimungkinkan masih ada beberapa variabel penjelas lainnya diluar model. Kelemahan pada penelitian ini cenderung mengabaikan beberapa variabel penjelas lainnya seperti dummy dewan pada perusahaan tersebut, karakteristik bank yang memberikan pinjaman dengan perusahaan yang bersangkutan, dan CEO power karena keterbatasan akses data penelitian. Selain itu, penelitian ini terbatas pada periode tahun 2011-2016. Oleh karena itu, pada penelitian selanjutnya, dapat menambahkan variabel independen lainnya tersebut. Selain itu, pada penelitian selanjutnya dapat melakukan pada durasi waktu yang lebih panjang misalnya dalam 10 tahun terakhir.

\section{DAFTAR PUSTAKA}

Agarwal, R., \& Elston, J. A. (2001). Bank-firm relationships, financing and firm performance in Germany. Economics Letters, 72, 225-232. 
Angori, G., Aristei, D., \& Gallo, M. (2019). Lending technologies, banking relationships, and firms' access to credit in Italy: the role of firm size. Applied Economics, 51(58), 6139-6170.

Aristei, D., \& Gallo, M. (2017). The determinants of firm-bank relationships in Italy: bank ownership type, diversification and multiple banking relationships. European Journal of Finance, 23(15), 1512-1543.

Belaid, F., Boussaada, R., \& Belguith, H. (2017). Bank-firm relationship and credit risk: An analysis on Tunisian firms. Research in International Business and Finance, 42(March), 532-543.

Bennett, M. S., \& Iqbal, Z. (2013). How socially responsible investing can help bridge the gap between Islamic and conventional financial markets. International Journal of Islamic and Middle Eastern Finance and Management, 6(3), 211-225.

Bennouri, M., Falconieri, S., \& Kooli, M. (2017). Single versus multiple banking: lessons from initial public offerings. The European Journal of Finance, 23(10), 841-858.

Bermpei, T., Kalyvas, A. N., Neri, L., \& Russo, A. (2019). Will Strangers Help you Enter? The Effect of Foreign Bank Presence on New Firm Entry. Journal of Financial Services Research, $56,1-38$.

Bolton, P., \& Scharfstein, D. S. (1996). Optimal Debt Structure and the Number of Creditors. The Journal of Political Economy, 104(1), 1-25.

Bonfim, D., Dai, Q., \& Franco, F. (2018). The number of bank relationships and borrowing costs: The role of information asymmetries. Journal of Empirical Finance, 46, 191-209.

Bonin, J. P., Hasan, I., \& Wachtel, P. (2005). Bank performance, efficiency and ownership in transition countries. Journal of Banking and Finance, 29(1), 31-53.

Brown, M., \& Hoffmann, M. (2016). Relationship Banking in the Residential Mortgage Market? Evidence from Switzerland. Swiss Society of Economics and Statistics, 152(1), 23-48.

Castelli, A., Dwyer, G. P., \& Hasan, I. (2011). Bank Relationships and Firms' Financial Performance: The Italian Experience. European Financial Management, 18(1), $28-67$.

Chen, S. H., \& Liao, C. C. (2011). Are foreign banks more profitable than domestic banks? Homeand host-country effects of banking market structure, governance, and supervision. Journal of Banking and Finance, 35(4), 819-839.

Cucculelli, M., Peruzzi, V., \& Zazzaro, A. (2019). Relational capital in lending relationships: evidence from European family firms. Small Business Economics, 52, 277-301.

Cui, W., Cuong, L. K., \& Shimizu, K. (2019). Cash policy and the bank-firm relationship. Economic Modelling, 91, 804-818.

Dass, N., \& Massa, M. (2011). The impact of a strong bank-firm relationship on the borrowing firm. Review of Financial Studies, 24(4), 1204-1260.

Dawar, V. (2014). Agency theory, capital structure and firm performance: some Indian evidence. Managerial Finance, 40(12), 1190-1206.

Detragiache, E., Paolo, G., \& Guiso, L. (2000). Multiple versus Single Banking Relationships: Theory and Evidence. Journal of Finance, 55(3), 1133-1162.

Ferrell, A., Liang, H., \& Renneboog, L. (2016). Socially responsible firms. Journal of Financial Economics. 122(3). 585-606.

Firdausi, R. M., \& Sulung, L. A. K. (2019). Peran Bank-Firm Relationship Terhadap Peningkatan Kinerja Perusahaan Non-Keuangan. Jurnal Akuntansi Multiparadigma, 10(1), 102-114. 
Fok, R. C. W., Chang, Y., \& Lee, W. (2004). Bank Relationships and Their Effects on Firm Performance around the Asian Financial Crisis: Evidence from Taiwan. Financial Management, 33(2), 89-112.

French, J. J., Yan, J., \& Yasuda, Y. (2019). Relationships Matter: the Impact of Bank-Firm Relationships on Mergers and Acquisitions in Japan. Journal of Financial Services Research, 56, 259-305.

Gama, A. P. M., \& Auken, H. Van. (2014). The Interdependence between Trade Credit and Bank Lending: Commitment in Intermediary Firm Relationships. Journal of Small Business Management, 53(4), 886-904.

Gambini, A., \& Zazzaro, A. (2013). Long-lasting bank relationships and growth of firms. Small Business Economics, 40, 977-1007.

Ghosh, S. (2015). How do Banks Influence Firm Capital Structure? Evidence from Indian Data. Indian Economic Review, 50(1), 1-24.

Ghosh, S. (2016). Small business, lending relationships and crisis: evidence from Indian micro data. Decision, 43(1), 1-15.

Ghosh, S. (2017). Ownership, evergreening and crisis: an analysis of bank-firm relationships in India. Macroeconomics and Finance in Emerging Market Economies, 11(2), 169-194.

Giannetti, M., \& Ongena, S. (2009). Financial Integration and Firm Performance: Evidence from Foreign Bank Entry in Emerging Markets. Review of Finance, 13(2), 181-223.

Go'mez-Gonza'lez, J. E., \& Reyes, N. R. (2011). The number of banking relationships and the business cycle: New evidence from Colombia. Economic Systems, 35, 408-418.

Greene, W. H. (2018). Econometric Analysis (8th ed.). Pearson Education.

Guiso, L., \& Minetti, R. (2010). The Structure of Multiple Credit Relationships: Evidence from U.S. Firms. Journal of Money, Credit and Banking, 42(6), 1037-1071.

Hindrayani, A. (2017). Bank-firm Relationships dan Kinerja Keuangan: Analisis pada Sektor Industri di Indonesia. JPEKA: Jurnal Pendidikan Ekonomi, Manajemen Dan Keuangan, $1(1), 1-7$.

Houston, J., \& James, C. (1996). Bank information monopolies and the mix of private and public debt claims. Journal of Finance, 51(5), 1863-1889.

Huang, R., Zhang, D., \& Zhao, Y. (Eddie). (2018). Relationship Banking and Loan Syndicate Structure: The Role of Private Equity Sponsors. The Financial Review, 53(3), 461-498.

Jadiyappa, N., Sireesha, B., Hickman, L. E., \& Jyothi, P. (2020). Multiple banking relationships, agency costs and firm value: evidence from India. Managerial Finance, 46(1), 1-18.

Jensen, M. C., \& Meckling, W. H. (1976). Theory of the firm: Managerial behavior, agency costs and ownership structure. Journal of Financial Economics, 3(4), 305-360.

Jeon, B. N., Olivero, M. P., \& Wu, J. (2011). Do foreign banks increase competition? Evidence from emerging Asian and Latin American banking markets. Journal of Banking and Finance, $78,200-214$.

Jha, A., Shankar, S., \& Arvi, L. (2014). Access to bank loans while in bankruptcy: the role of single vs. multiple banking relations. Managerial Finance, 40(7), 724-733.

Karaivanov, A., Saurina, J., \& Townsend, R. M. (2019). Family firms, bank relationships, and financial constraints: A comprehensive score card. International Economic Review, 60(2), 547-593. 
Kysucky, V., \& Norden, L. (2015). The Benefits of Relationship Lending in a Cross-Country Context: A Meta-Analysis. Management Science, 62(1), 90-110.

Lee, M. (2020). Does a firm's access to external finance matter for its performance? Applied Economics Letters, 27(9), 725-728.

Lin, H. (2011). Foreign bank entry and firms' access to bank credit: Evidence from China. Journal of Banking and Finance, 35(4), 1000-1010.

Liu, Y., Fujiwara, K., Jinushi, T., \& Yamori, N. (2016). How Should Banks Support SMEs to Manage Funding Risks in China? The Role of Relationship Banking. Risk Management in Emerging Markets, 365-398.

López-Espín, J. J., Vidal, A. M., \& Giménez, D. (2012). Two-stage least squares and indirect least squares algorithms for simultaneous equations models. Journal of Computational and Applied Mathematics, 236(15), 3676-3684.

Mustapha, M., \& Ahmad, A. C. (2011). Agency theory and managerial ownership: evidence from Malaysia. Managerial Auditing Journal, 26(5), 419-436.

Ogawa, K., Sterken, E., \& Tokutsu, I. (2007). Why do Japanese firms prefer multiple bank relationship? Some evidence from firm-level data. Economic Systems, 31(1), 49-70.

Ongena, S., \& Yu, Y. (2017). Firm Industry Affiliation and Multiple Bank Relationships. Journal of Financial Services Research, 51,1-17.

Pantjes, R., \& Tümer-Alkan, G. (2017). Firms' Choice of Financiers in M\&A Deals: The Value of Bank-Firm Relationships. Economic Notes, 46(3), 633-648.

Paul, O. U. (2017). The Impact of Leverage Financing on Financial Performance of Some Manufacturing Industries in Nigerian Stock Exchange. Saudi Journal of Business and Management Studies, 2(7), 716-726.

Pennathur, A., \& Vishwasrao, S. (2014). The financial crisis and bank-client relationships: Foreign ownership, transparency, and portfolio selection. Journal of Banking and Finance, 42(1), 232-246.

Petersen, M. A., \& Rajan, R. G. (1994). The Benefits of Lending Relationships: Evidence from Small Business Data. Journal of Finance, 49(1), 3-37.

Rajan, R. G. (1992). Insiders and Outsiders: The Choice Between Informed and Arm's Length Debt. Journal of Finance, 47(4), 1367-1400.

Refait-Alexandre, C., \& Serve, S. (2020). Multiple banking relationships: Do SMEs mistrust their banks? Research in International Business and Finance, 15, 1-18.

Shikimi, M. (2013). Do firms benefit from multiple banking relationships? Evidence from small and medium- sized firms in Japan. International Economics and Economic Policy, 10, 127 157.

Stein, I. (2015). The Price Impact of Lending Relationships. German Economic Review, 16(3), 367-389.

Stephan, A., Tsapin, A., \& Talavera, O. (2014). Main Bank Power, Switching Costs, and Firm Performance: Theory and Evidence from Ukraine. Emerging Markets Finance and Trade, 48(2), 76-93.

Takahashi, H. (2014). The Effect of Bank-firm Relationships on Sell-side Research. Journal of Financial Services Research, 46, 195-213. 
Tsapin, A. (2017). Do firm-bank relationships affect corporate cash holdings? Visnyk of the National Bank of Ukraine, 241, 5-20.

Werner, R. A. (2016). A lost century in economics: Three theories of banking and the conclusive evidence. International Review of Financial Analysis, 46, 361-379.

Wooldridge, J. M. (2016). Introductory Econometrics (6e ed.). Boston MA: Cengage Learning.

Yin, W., \& Matthews, K. (2017). Bank lending and bank relationships in China: guanxi or commercial? Managerial Finance, 43(4), 425-439.

Zemzem, A., Guesmi, K., \& Ftouhi, K. (2017). The Role of Banks in the Governance of NonFinancial Firms: Evidence from Europe. Research in International Business and Finance, 42, 285-294. 